\title{
Introduction
}

\section{Rights-Bearing and Duty-Bound: Governing Women}

\section{Julie Murray}

The death of Toronto physician and psychotherapist Suzanne KillingerJohnson in August 2000, days after she jumped - in the throes of a severe postpartum depression and clutching her six-month-old son - in front of a subway train, removed the vexed question of whether she was to be charged with murder in the boy's death. Breathing a collective sigh of relief, local authorities and newspaper editorialists alike would not be forced to wrestle with the range of menacing questions - legal, medical, psychiatric, political - that arose from the event. Rather, what had been a homicide investigation quickly became a coroner's inquiry, with the burden of censure displaced by, and finally recuperated in, a chorus of "why?" The inexplicability of the event seemed to turn on the unlikelihood of Killinger-Johnson as a candidate for such a tragedy. Repeatedly referring to the fact that she came from a "family of prominent professionals," and enjoyed a "life of affluence and success in one of the city's more fashionable neighbourhoods" with her husband and their new son, editorialists scratched their heads and turned, expectantly, to the medical "experts," who proved to be equally baffled.

The rhetoric of anomaly prevailed in the media response to the event and its aftermath. ${ }^{1}$ The Globe and Mail's Michael Valpy reported that

It is among the rarest of acts known to criminologists and medical psychopathologists: a woman who with her infant son in her arms leaps to almost certain death. What happened to Suzanne KillingerJohnson and her six-month-old son in a Toronto subway station yesterday morning is so atypical that the clinical medical literature on major postpartum depression - the most common complication of childbirth - doesn't allude to it. The literature says a mother suffering from the condition may be at risk of harming herself, or that an infant may be at risk of being harmed by its mother. But not both. (A1) 
The infanticide-suicide was thus doubly unlikely: not only do most mothers not kill themselves and their infants, but women like her are not supposed to do this. Poor, single mothers, homeless mothers, and abused mothers come to mind, not mothers with promising careers, expensive cars, and mortgage-free homes, mothers who so perfectly realize neoliberalism's fantasy of unfettered "freedom."

If the language of rights and freedoms has become virtually synonymous with the realm of the political, the older language of duty, obligation, and responsibility that it displaced is what we generally associate with an ethical sphere. In feminist theory, Luce Irigaray is one of the foremost theorists of an ethics that must, she argues, take as its foundation sexual difference. "Replacing the one by the two of sexual difference," she suggests, in "The Question of the Other,"

thus constitutes a decisive philosophical and political gesture, one which gives up a singular or plural being [l'être un ou pluriel] in order to become a dual being [l'etre deux]. This is the necessary foundation for a new ontology, a new ethics, and a new politics, in which the other is recognized as other and not as the same: bigger or smaller than I, or at best, my equal. (19)

To those who would protest, and many have, that Irigaray in effect universalizes the heterosexual relation as the model for all relations of alterity or difference, others, such as Elizabeth Grosz, would respond with the following question: "what would other relations of sexuality be like if and when there was a recognition of the existence of more than one sex? [...] What changes would there be to homosexuality, to love between women, between men, to sexual love of all kinds, if this recognition were possible?" (28). Irigaray's ethics of sexual difference is, thus, an impossible ethics, in that the conditions of its possibility exist in nature - "Sexual difference is an immediate natural given" - but the realization of those conditions have yet to make their way into culture, into the legal and political structures that govern our lives (ILTY 47). In Sexes and Genealogies, Irigaray offers a concrete proposal with her suggestion that "what is needed is a full-scale rethinking of the law's duty to offer justice to two genders that differ in their needs, their desires, their properties...If the rights of the couple were indeed written into the legal code, this would serve to convert individual morality into collective ethics" (5). 
The "individual morality" to which Irigaray refers is an effect of this violent logic of the one, as opposed to the being-two that founds her impossible ethics. This logic of sameness is that which grounds the patriarchal family, that mainstay of modern liberal democracies (not to mention the version of sameness - equality before the law - that grounds liberalism). Because we have, as yet, no socio-cultural, legal or political recognition that there exists more than one sex, within the context of the private family, Irigaray suggests, "The woman is wife and mother."

But for her, this role is a function of an abstract duty. So she is not this woman, irreducible in her singularity, wife of this man, who is himself also irreducible, any more than she is this mother of this child or these children...In other words, a woman's love is defined as familial and civil duty. She has no right to singular love nor to love for herself. She is thus unable to love but is to be subjugated to love and reproduction. She has to be sacrificed and to sacrifice herself to this task, at the same time disappearing as this or that woman who is alive at the present time. And she must disappear as desire too, unless it is abstract: the desire to be wife and mother. This self-effacement in a family-related role is her civil task. (ILTY 21)

This particular kind of mother-love has long been exploited for the way in which it naturalizes the mother-child relationship, and ordains it as the exemplary ethical relationship, so that a mother's duty and obligation to her child (and family) precedes any contractual claim to political rights or freedoms. For Irigaray, this model of the mother-child relationship is not ethical precisely because it is premised on patriarchal relations of the reproduction of sameness, and thus constitutes an ethics of the one, not the two. In this context it is the mother's duty that prevents her from acceding to the kind of rights-bearing status associated with the political sphere. In Irigaray's formulation of an ethics of sexual difference, however, the realm of the political is the precondition for an opening onto the ethical. Until the sexual difference of being-two is inscribed in law, there is no possibility of the ethics that Irigaray describes. An ethics of sexual difference, for Irigaray, would thus proceed from the political, not towards it.

The centuries-old figure of the duty-bound mother as moral exemplar has been deployed perhaps most strategically - put to work as it were - in the service of what Foucault would call the "conduct of conduct," or 
governmentality, understood as the paradigmatic exercise of power in liberal democratic states. Following Foucault, Nikolas Rose has emphasized that since liberal democracies limit the power of government to intervene in the lives of individual citizens, what he calls "technologies of subjectivity" - a prime example of which is psychotherapy, along with its popularization in contemporary recovery movements - have come to act in the place of more direct apparatuses of government. For Rose, freedom is by no means opposed to government or regulation, but rather is the very principle of governance. The Killinger-Johnson example is a case in point. "The night before she jumped," wrote Margaret Wente in The Globe and Mail,

the young doctor [Killinger-Johnson] was apprehended at a subway station with her baby son, Cuyler, in her arms. She gave a false name. Intercepted again at another station, she allowed the police to take her quietly home to her husband. She convinced them all she was not out of control, not crazy, not psychotic. Less than seven hours later, she strapped her infant into the baby seat of her silver Mercedes SUV. She drove to a parking lot she knew was across the street from a subway entrance. She ignored a security guard who said it was too early to park there. She took the baby out of his seat, and smiled politely at someone handing out free newspapers. She walked into the station, straight through the crowd of early morning commuters, and jumped in front of the first northbound train that came along. (A1)

In Wente's narrative, Killinger-Johnson's actions were the result of rational - even cold - and free calculation, and careful, meticulous strategy. Killinger-Johnson eluded the full force of law, of discipline, because, according to Wente, she possessed a kind of expertise in conduct that allowed her to convince those who wished to take her into custody that she was "not out of control, not crazy, not psychotic." Because she was able to perform certain norms of conduct, she was delivered into the "safety" of her family, without question, away from the prying and prodding of social workers and psychologists. In the aftermath of Killinger-Johnson's death, Maclean's magazine ran a story on depression amongst physicians, and cited a psychiatrist who - treating only physicians in his practice suggested that "when a physician is depressed, he or she suffers an even greater degree of guilt, shame, failure and the isolation that goes with that." 
Pointing to a higher rate of suicide amongst medical professionals, along with the tendency for physicians to self-diagnose rather than visit a professional themselves, the article concludes by citing the various "physician self-awareness programs" that have sprung up in medical schools across the country, which aim to dispel the "myth of invulnerability" that surrounds the profession, and train medical students to "ask for help" and make "self-care" a "core value in medical school" (39). Killinger-Johnson, a psychotherapist and physician in a family of psychotherapists and physicians, whose job it was to treat other professionals, was undoubtedly familiar with the therapeutic turn in medical schools. Whatever happened to Killinger-Johnson, it wasn't from any lack of intimacy with techniques of government.

The tragedy, for Wente, is that Killinger-Johnson "behaved perfectly normally." She continues, "But that's what highly competent people do. They are on their best behaviour, even as their inner worlds collapse...It sometimes seems to me that the more able and gifted the sufferers, the more insidious is the course of this disease. People such as Suzanne Killinger-Johnson hold themselves to the highest standards. They expect themselves to manage through it." Killinger-Johnson's ability to appear "normal" enabled the tragedy because, according to Wente, it allowed her to escape the interventions and ministrations of either the authorities or her family. Moreover, the failure of government happened at the moment at which Killinger-Johnson, precisely because she "behaved perfectly normally," managed to get away, and had nobody attending her. Rehearsing Killinger-Johnson's actions, Wente deploys the rhetoric of appearance in order to accentuate that the tragedy turned on an inability by those who were in charge - the authorities, her family - to penetrate the woman's act. Government failed, according to this logic, to truly know the governed. One might argue, however, quite to the contrary, that the tragedy in this case was not one of too little or insufficient government, but too much. The very capacity to reiterate norms of conduct is an effect of government, a sign of its intimate presence, not its absence. Indeed, the much-vexed irrationality of Killinger-Johnson's death derives in large part from her doubly exemplary status: she is at once the paradigm of the governmental technocrat and the duty-bound mother. Her death is incomprehensible to commentators not merely because she managed to escape the ministrations of both government and family, but precisely because she embodies the fundamental principles of those institutions and 
the moral order that supports them.

Implicit in the chorus of "why?" that followed Killinger-Johnson's death was the question: "how could this happen to someone like her, someone so normal?" Generally not asked when someone unlike Killinger-Johnson dies - the homeless, poor, single mother, for instance - the question, in its attempt to make sense of her death, inadvertently reinscribed the very norms it might otherwise have interrogated. Cases unlike KillingerJohnson's derive their explanatory power by locating the necessarily pathologized mother/victim outside the ethical and social norm. Thus, unable to arrive at an even remotely satisfying motivation or cause, one which those cases unlike Killinger-Johnson's can supply, the media discourse about Killinger-Johnson registered a kind of limit or crisis of knowledge. In the absence of a compelling material reason for the infanticide-suicide (the post-partum depression, though perfectly material, was necessarily too mystified in the media coverage to serve this particular purpose), a spectre arose that generally doesn't haunt cases unlike Killinger-Johnson's. In posing the question "why?" the media opened up the possibility of a line of question that, though not pursued, made its presence felt. The question "why?" remarks the limit of what it is possible to ask within the terms of our ethical order. If the figure of the mother-child relationship constitutes the ethical ground of the patriarchal family, and by extension society, then as ground it also constitutes a kind of limit, one which can never be approached. The mother-child relationship is, thus, the occluded origin from which our ethical norms are generated. This is, of course, what Irigaray calls the logic of sacrifice, and that which she calls into question with her critique of the ethics of the one, those ethical norms the paucity of which the Killinger-Johnson case lays bare. Because Killinger-Johnson doubly embodies the fundamental principles of the hegemonic ethical paradigm, the widespread media appeal to the unanswerable or impossible question simply underlined an unwillingness to interrogate the foundation of that question in those ethics. A feminist ethics might begin by attempting to approach the limit which the KillingerJohnson case exposes. This issue of Tessera is oriented in that direction and to that task. 


\section{Notes}

Thanks to Lauren Gillingham and Craig Gordon for their comments and suggestions on an earlier draft.

${ }^{1}$ This insistence on the exceptionality of the event raises the spectre of the media response to the 1989 Montreal Massacre, in which, as many feminists remarked, an undue focus on the singularity of both the act and its perpetrator deflected attention from its wider social and political implications and determinations.

\section{Works Cited}

Cheah, Pheng, and Elizabeth Grosz. "Of Being-Two: Introduction." Diacritics. 28:1 (1998) 3-18.

-. "The Future of Sexual Difference: An Interview with Judith Butler and Drucilla Cornell." Diacritics. 28:1 (1998) 19-41.

Foucault, Michel. "Governmentality." The Foucault Effect: Studies in Governmentality. Eds. Graham Burchell et al. London: Harvester / Wheatsheaf, 1991.

Hawkes, Cheryl. "So much to live for: doctors confront the myth of their invulnerability." Maclean's. 28 Aug. 2000: 39.

Irigaray, Luce. I Love to You: Sketch of a Possible Felicity in History. Trans. Alison Martin. New York: Routledge, 1996.

---. "The Question of the Other." Trans. Noah Guynn. Yale French Studies 87 (1995): 7-19.

---. Sexes and Genealogies. Trans. Gillian Gill. New York: Columbia UP, 1993.

Rose, Nikolas. Inventing Ourselves: Psychology, Power, and Personhood. Cambridge: Cambridge UP, 1996.

- Governing the Soul: The Shaping of the Private Self. London: Routledge, 1990.

Valpy, Michael. "The experts are left baffled: Case defies conventional wisdom." The Globe and Mail. 12 Aug. 2000: A1+.

Wente, Margaret. "Suicide attempt provides most difficult of questions." The Globe and Mail. 15 Aug. 2000: A1+. 